\title{
A Case of Temporal Arteritis Associated with Atypical Clinical Findings
}

\author{
Asfuroglu $\mathrm{M}^{1 *}$, Koz OG ${ }^{1}$, Ozbalkan $\mathrm{Z}^{2}$, Kulacoglu $\mathrm{S}^{3}$, Sandikci SC ${ }^{2}$ and Ozdemir EY${ }^{1}$ \\ ${ }^{1}$ Department of Ophthalmology, Ankara Numune Education and Research Hospital, Turkey \\ ${ }^{2}$ Department of Rheumatology, Ankara Numune Education and Research Hospital, Turkey \\ ${ }^{3}$ Department of Pathology, Ankara Numune Education and Research Hospital, Turkey
}

Submission: April 07, 2017; Published: June 06, 2017

*Corresponding author: Asfuroglu M, Ankara Numune Education and Research Hospital, Ophthalmology Clinic, Ankara, Turkey,

Email: drmaasfur@hotmail.com

\begin{abstract}
Introduction: We describe a case of temporal arteritis associated with a typical clinical findings, that affected both eyes of the patient with in a 1 month interval.

Case report: A 63 years old hypertensive male patient applied to our clinic with complaint of vision loss in his right eye for two weeks. His visual acquity was perception of hand movements in right eye. He did not complain of any associated headache, scalp tenderness, jaw claudication or constitutional symptoms such as weight loss, fever, malaise or sweats. We consulted the patient to internal medicine, rheumotology and hematology departments. His clinical and labaratuary findings were unremarkable except thrombocytosis. Following a presumptive diagnosis of non-arteritic ischemic optic neuropathy, the patient was hospitalized and treated with intravenous $1000 \mathrm{mg}$ methylprednisolone for 3 days. After 3 days, oral prednisolone therapy was started $60 \mathrm{mg}$ per day. Oral steroid therapy was tapered $10 \mathrm{mg}$ with 3 days interval. 1 month later, patient presented with sudden vision loss in his left eye. Fundus examination revealed left optic disc swelling and soft exudates near the optic disc.
\end{abstract}

Conclusion: In people older than 55 years, amaurosis fugax or visual loss, development of an acute ocular ischemic lesion with or without elevated erythrocyte sedimentation rate and systemic symptoms, should raise suspicion for giant cell arteritis.

\section{Introduction}

Giant cell arteritis (GCA), is a systemic vasculitis, affects medium and large sized cranial arteries [1], it can cause serious morbidities. Giant cell arteritis (GCA) predominantly affects elderly females [2]. The typical symptoms of new-onset GCA are bitemporal headaches, jaw claudiacation, scalp tenderness, visual disturbances, systemic symptoms such as fever and weight loss, and polymyalgia [3]. The diagnostic assessment comprises laboratory testing (erythrocyte sedimentation rate, C-reactive protein), temporal artery biopsy and imaging studies. The most important complication is permenant and deep vision loss. Diagnosis of TA is difficult if typical symptoms other than visual loss are absent. It can be difficult to diagnose this disease in the absence of typical clinical signs and labaratuary findings. Here we report a silent and atypical temporal arteritis case (Table 1\& 2).

Table 1: Symptoms in Giant Cell Arteritis [3].

\begin{tabular}{|l|c|}
\hline \multicolumn{1}{|c|}{ Category } & Symptoms \\
\hline \multirow{4}{*}{ 5Symptoms due to involvement of cranial vessels } & Headache \\
\cline { 2 - 2 } & Jaw claudication (pain on chewing) \\
\cline { 2 - 2 } & Scalp tenderness \\
\cline { 2 - 2 } & Loss of vision \\
\cline { 2 - 2 } & Abnormalities of the temporal artery \\
\cline { 2 - 2 } & (pain, nodules, absence of pulse) \\
\hline
\end{tabular}




\begin{tabular}{|c|c|}
\hline $\begin{array}{c}\text { Symptoms due to involvement of great vessels (aorta and branches } \\
\text { of aorta) }\end{array}$ & Claudication of extremities (especially arm) \\
\hline Symptoms due to systemic inflammation & Fever, night sweats, weight loss \\
\hline Polymyalgia rheumatica & $\begin{array}{c}\text { Mainly proximal myalgia and stiffness of the neck and shoulder and pelvic } \\
\text { girdle }\end{array}$ \\
\hline
\end{tabular}

Table 2: The American College of Rheumatology classification criteria [4] for GCA.

\begin{tabular}{|r|}
\hline$\bullet$ Age at disease onset: development of symptoms or findings beginning at the age of $\geq 50$ years. \\
\hline$\bullet$ New headache: new onset of or new type of localised pain in the head. \\
\hline$\bullet$ Temporal artery abnormality: temporal artery tenderness to palpation or decreased pulsation, unrelated to arteriosclerosis of cervical arteries. \\
\hline$\bullet$ Elevated ESR: ESR $\geq 50 \mathrm{~mm} /$ hour. \\
\hline Abnormal artery biopsy: biopsy specimen with artery showing vasculitis characterised by a predominance of mononuclear cell infiltration or \\
granulomatous inflammation, usually with multinucleated giant cells.
\end{tabular}

\section{Case Report}

63 year old hypertensive male patient applied to our hospital with complaint of vision loss in his right eye for two

weeks. His visual acquity was perception of hand movements in right eye and 8/10 according to Snellen Chart in left eye. While anterior segment evaluation revealed bilateral nuclear sclerosis, fundoscopic examination revealed papiledema in his right eye. He did not complain of any associated headache, scalp tenderness, jaw claudication or constitutional symptoms such as weight loss, fever, malaise or sweats. We consulted the patient to internal medicine, rheumotology and hematology departments. His clinical and labaratuary findings were unremarkable except thrombocytosis. Following a presumptive diagnosis of nonarteritic ischemic optic neuropathy the patient was hospitalized and treated with intravenous $1000 \mathrm{mg}$ methylprednisolone for 3 days. After 3 days, oral prednisolone therapy was started $60 \mathrm{mg}$ per day. Oral steroid therapy was tapered $10 \mathrm{mg}$ with 3 days interval. However at 10-days' examination visual acquity in his right eye was reduced to loss of light perception. 1 month later, patient presented with sudden vision loss in his left eye, headache and malaise. Fundus examination revealed left optic disc swelling and soft exudates near the optic disc (Figure 1). Floroscein anjiography showed delayed filling at arterial phase and late staining of the optic disc. When labaratuary tests were repeated, erythrocyte sedimentation rate (ESR) was $65 \mathrm{~mm} /$ $\mathrm{h}($ normal range: $1-15 \mathrm{~mm} / \mathrm{h}$ ) and creactive protein (CRP) level was $15 \mathrm{mg} / \mathrm{L}$ (normal range: $<5 \mathrm{mg} / \mathrm{L}$ ). According to these findings, with the diagnosis of arteritic ischemic optic neuropathy, intravenous steroid therapy was initiated. Rheumatology department evaluated the patient again and a temporal artery biopsy was performed; focal chronic inflammation and elastic fiber degeneration areas were identified at histologic sections (Figure 2). At the fifth day of intravenous steroid therapy visual acquity in left eye was $7 / 10$ according to the Snellen Chart. The
Humphrey Perimetry test revealed a paracentral island in his left eye.Since the visual acquity was at the level of loss of light perception at the right eye we didn't perform the Humphrey Perimetry test for the right eye.

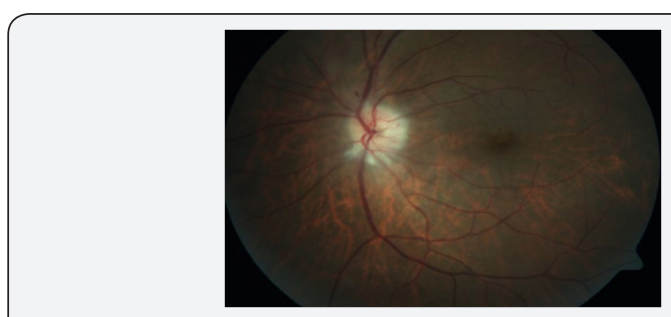

Figure 1: Left optic disc swelling and soft exudate near the optic disc , 1 month later after first presentation.

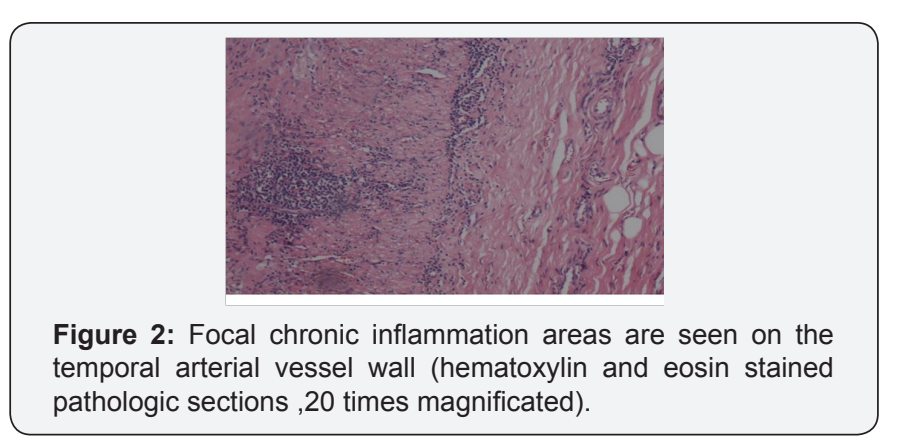

\section{Discussion}

Patients with GCA typically present headache, jaw claudication, fever, weight loss, myalgia, arthralgia or malaise. Conversely, patients with occult GCA, first described by Simmons \& Cogan [5], present with sudden visual loss without systemic symptoms and signs. Thus, due to the lack of symptoms, diagnosis and treatment of silent GCA may be considerably delayed when compared to typical GCA. Occult GCA , a potential cause of blindness, is defined as ocular involvement of GCA without any systemic symptoms and signs [6]. Ocular symptoms include visual loss, amaurosis fugax, diplopia and eye pain 
Hayreh et al. [6], described cotton wool spots in up to one third of eyes with visual loss during the early stages of occult GCA [6]. Scalp abcess, chronic earache, bilateral central retinal artery occlusion, mydriaitic pupil, dry cough, aort anevrism , bilateral submandibular lymphadenopathy, hepatosplenomegaly are some atypic symptoms of GCA. The occult GCA group had higher C-reactive protein levels, a higher platelet count, and lower serum albumin levels [7]. Ophthalmic involvement can occur in up to $50 \%$ to $70 \%$ of the GCA patients, and this represents an ocular emergency. Arteritic anterior ischemic optic neuropathy (AAION) is the most common type of ophthalmic involvement in GCA and can cause permanent visual loss. Therefore, prompt diagnosis and treatment with a high dose of steroids is essential for these patients. In our patient at the first presentation labaratuary findings were unremarkable and there were no systemic symptoms; therefore at the beginning, our presumptive diagnosis was non-arteritic ischemic optic neuropathy of right eye. 1 month later, sudden vision loss appeared at left eye and he was complaining from headache, scalp tenderness ; ESR and CRP levels were elevated on labaratuary examination at that time. Hayreh et al. [6] found that ESR and CRP levels were relatively lower in patients with occult GCA compared to cranial GCA. On the other hand, Hamidou et al. [7] found higher CRP levels, a higher platelet count, and lower serum albumin levels in occult GCA group. In our patient's first presentation, ESR and CRP levels were within the normal limits. One month later when the other eye was effected ESR and CRP levels were remarkably high (Figure 3).

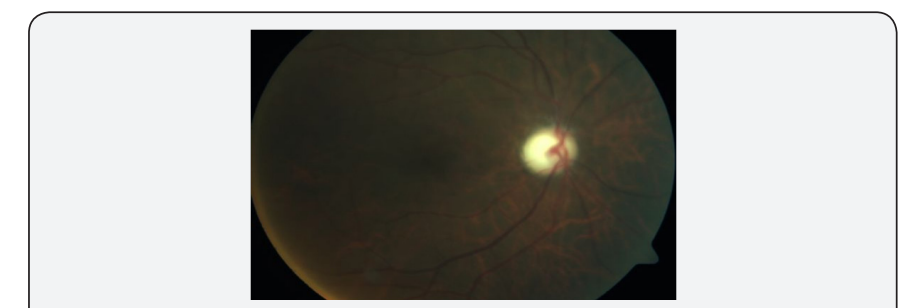

Figure 3: Right optic disk appearance after 1 month of visual loss.

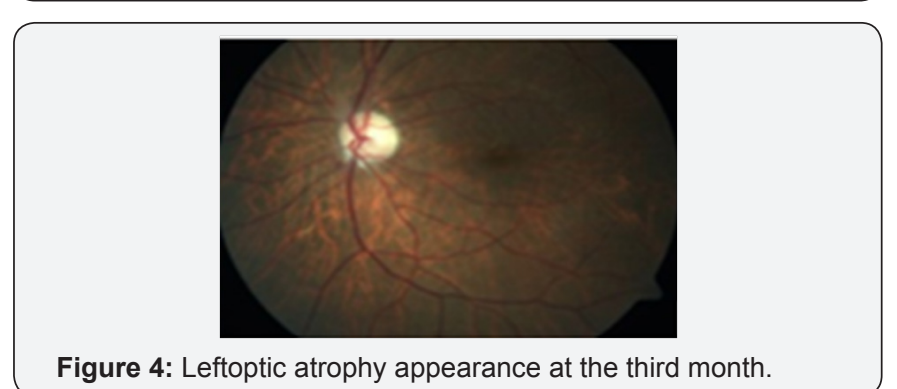

Although Liozon et al. [8] describes occult GCA as a protracted inflammatory response and a relatively benign short term outcome, in our case despite the long term corticosteroid and immunsupresive treatment, visual acquity was loss of light perception level in the right eye. Tan et al. [9] reported a case of GCA involving only the occipital artery which was revealed by magnetic resonance angiography. Chomlak et al. [10] reported a case of GCA with vertebral artery involvement, which was refractory to immunosuppressives. Hocevar et al. [11] claimed that, even early diagnosis and a prompt initiation of steroid did not prevent relapses in GCA. In our case after first attack despite the prompt intravenous steroid therapy one month later the patient consulted with visual loss at his other eye this verified Hocevar's hypothesis. Cullen et al. [12] reported an occult GCA case in Singapore. Papakostas et al. [13] reported a case of GCA that presented with cotton wool spots and retinal vasculitis affecting small-size retinal arterioles. Shambhu et al. [14] reported an atypical case of GCA presenting as mild upper abdominal pain and generalized weakness in the context of hyponatremia as the presenting manifestation of vasculitis that was subsequently diagnosed by MRI scanning. Cheema et al. [15] described a case had the signs and symptoms consistent with GCA but who had an ESR within the normal limits, $27 \mathrm{~mm} / \mathrm{h}$. In our case ESR at the first presenting ESR was within the normal limits,too. Labarca et al. [16] reported that patients with hypertension or diabetes at GCA diagnosis have more relapses during follow-up. Kermani et al. [17] reported seven patients with a positive temporal arteritis for GCA had a normal ESR and CRP at diagnosis (Figure 4).

In people older than 55 years, amaurosis fugax or visual loss, development of an acute ocular ischemic lesion with or without elevated erythrocyte sedimentation rate and systemic symptoms, should raise suspicion for giant cell arteritis. The diagnosis of temporal arteritis is easily made when sudden loss is contemporary with other symptoms and raised inflammatory markers. In the absence of known symptoms, in a patient diagnosed as ischemic optic neuropathy, occult temporal arteritis shouldn't be out of mind. Despite the early diagnosis and treatment final visual acquity may not be satisfactory.

\section{Conflict of Interest}

Asfuroglu declares that he has no conflict of interest. Author Koz declares that she has no conflict of interest. Author Ozbalkan declares that she has no conflict of interest. Author Sandikci declares that she has no conflict of interest. Author Ciftci declares that she has no conflict of interest. Author Ozdemir declares that she has no conflict of interest.

This article does not contain any studies with human participant performed by any of the authors.

Informed consent was obtained from all individual participants included in the study.

\section{References}

1. Gran JT (2002) Some thoughts about the etiopatho genesis of temporal arteritis -a review. Scand J Rheumatol 31: 1-5.

2. Salvarani C, Crowson CS, O'Fallon WM (2004) Reappraisal of the epidemiology of giant cell arteritis in Olmsted County, Minnesota, over a fifty year period. Arthritis Rheum 51(2): 264-268. 
3. Ness T, Bley TA, Schmidt WA, Lamprecht P (2013) The Diagnosis and Treatment of Giant Cell Arteritis. Dtsch Arztebl Int 110(21): 376-386.

4. Hunder GG, Bloch DA, Michel BA, Stevens MB, Arend WP, et al (1990) The American collage of rheumatology 1990 criteria for the classification of giant cell arteritis. Arthritis Rheum 33(8): 1122-1128

5. Simmons RJ, Cogan DG (1962) Occult temporal arteritis. Arch Ophthalmol 68: 38-48.

6. Hayreh SS, Podhajsky PA, Zimmerman B (1998) Occult giant cell arteritis: ocular manifestations. Am J Ophthalmol 125(4): 521-526

7. Hamidou MA, Batard E, Trewick D (2005) Silent versus cranial giant cell arteritis. Initial presentation and outcome of 50 biopsy-proven cases Eur J Int Med 16(3): 183-186

8. Liozon E, Boutros-TF, Ly K (2003) Silent, or masked, giant cell arteritis is associated with a strong inflammatory response and a benign short term course. J Rheumatol 30(6): 1272-1276.

9. Tan BL, Liu JJ, Tuck Y (2016) Diagnosing an atypical site of giant cell arteritis with magnetic resonance angiography: a case report. J Med Case Rep 10: 179

10. Chomlak RD, Ghazanfari F, Datta M (2016) Case Study: Giant Cell Arteritis with Vertebral Artery Stenosis. Clin Med Insights Arthritis Musculoskelet Disord 9: 103-107.

11. Hocevar A, Rotar Z, Jese R (2016) Do Early Diagnosis and Glucocorticoid Treatment Decrease the Risk of Permanent Visual Loss and Early

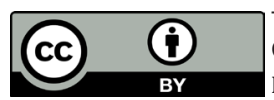

This work is licensed under Creative Commons Attribution 4.0 License

DOI:10.19080/JOJ0.2017.03.555612
Relapses in Giant Cell Arteritis: A Prospective Longitudinal Study Medicine (Baltimore) 95(14): e3210

12. Cullen JF, Chan BMJ, Wong CF (2010) Giant cell (temporal) arteritis in Singapore: an occult case and the rationale of treatment. staining Singapore Med J 51(1): 73.

13. Papakostas TD, Jakobiec FA, Stagner AM (2016) Small-Caliber Retinal Vasculitis Associated With Giant Cell Arteritis: A New Finding. Ophthalmic Surg Lasers Imaging Retina 47(11): 1054-1056.

14. Shambhu S, Suarez L (2016) Giant Cell Arteritis: An Atypical Presentation Diagnosed with the Use of MRI Imaging. Case Rep Rheumatol.

15. Cheema MR, Ismaeel SM (2016) Temporal arteritis with erythrocyte sedimentation rate $<50 \mathrm{~mm} / \mathrm{h}$ : a clinical reminder. Clin Interv Aging 11: $185-188$.

16. Labarca C, Koster MJ, Crowson CS, Makol A, Ytterberg SR (2016) Predictors of relapse and treatment outcomes in biopsy-proven giant cell arteritis: a retrospective cohort study. Rheumatology (Oxford) 55(2): 347-356

17. Kermani TA, Schmidt J, Crowson CS, Ytterberg SR, Hunder GG (2012) Utility of Erythrocyte Sedimentation Rate and C-Reactive Protein for the Diagnosis of Giant Cell Arteritis. Semin Arthritis Rheum 41(6): 866-871.

\section{Your next submission with Juniper Publishers} will reach you the below assets

- Quality Editorial service

- Swift Peer Review

- Reprints availability

- E-prints Service

- Manuscript Podcast for convenient understanding

- Global attainment for your research

- Manuscript accessibility in different formats

( Pdf, E-pub, Full Text, Audio)

- Unceasing customer service

Track the below URL for one-step submission https://juniperpublishers.com/online-submission.php 